\title{
The Impact of Differentiation on Cytotoxicity and Insulin Sensitivity in Streptozotocin Treated SH-SY5Y Cells
}

\author{
Fruzsina Bagaméry ${ }^{1} \cdot$ Kamilla Varga $^{1} \cdot$ Kitti Kecsmár $^{1} \cdot$ István Vincze $^{1} \cdot$ Éva Szökö $^{1} \cdot$ Tamás Tábi $^{1}$ (1)
}

Received: 22 November 2020 / Revised: 1 February 2021 / Accepted: 5 February 2021 / Published online: 22 February 2021

(c) The Author(s) 2021

\begin{abstract}
Recently neuronal insulin resistance was suggested playing a role in Alzheimer's disease. Streptozotocin (STZ) is commonly used to induce impairment in insulin metabolism. In our previous work on undifferentiated SH-SY5Y cells the compound exerted cytotoxicity without altering insulin sensitivity. Nevertheless, differentiation of the cells to a more mature neuronlike phenotype may considerably affect the significance of insulin signaling and its sensitivity to STZ. We aimed at studying the influence of STZ treatment on insulin signaling in SH-SY5Y cells differentiated by retinoic acid (RA). Cytotoxicity of STZ or low serum (LS) condition and protective effect of insulin were compared in RA differentiated SH-SY5Y cells. The effect of insulin and an incretin analogue, exendin-4 on insulin signaling was also examined by assessing glycogen synthase kinase-3 (GSK-3) phosphorylation. STZ was found less cytotoxic in the differentiated cells compared to our previous results in undifferentiated SH-SY5Y cells. The cytoprotective concentration of insulin was similar in the STZ and LS groups. However, the right-shifted concentration-response curve of insulin induced GSK-3 phosphorylation in STZ-treated differentiated cells is suggestive of the development of insulin resistance that was further confirmed by the insulin potentiating effect of exendin-4. Differentiation reduced the sensitivity of SH-SY5Y cells for the non-specific cytotoxicity of STZ and enhanced the relative significance of development of insulin resistance. The differentiated cells thus serve as a better model for studying the role of insulin signaling in neuronal survival. However, direct cytotoxicity of STZ also contributes to the cell death.
\end{abstract}

Keywords GLP-1 analogue · Glycogen-synthase kinase-3 · Insulin resistance · SH-SY5Y cell line · Streptozotocin · Retinoic acid induced differentiation

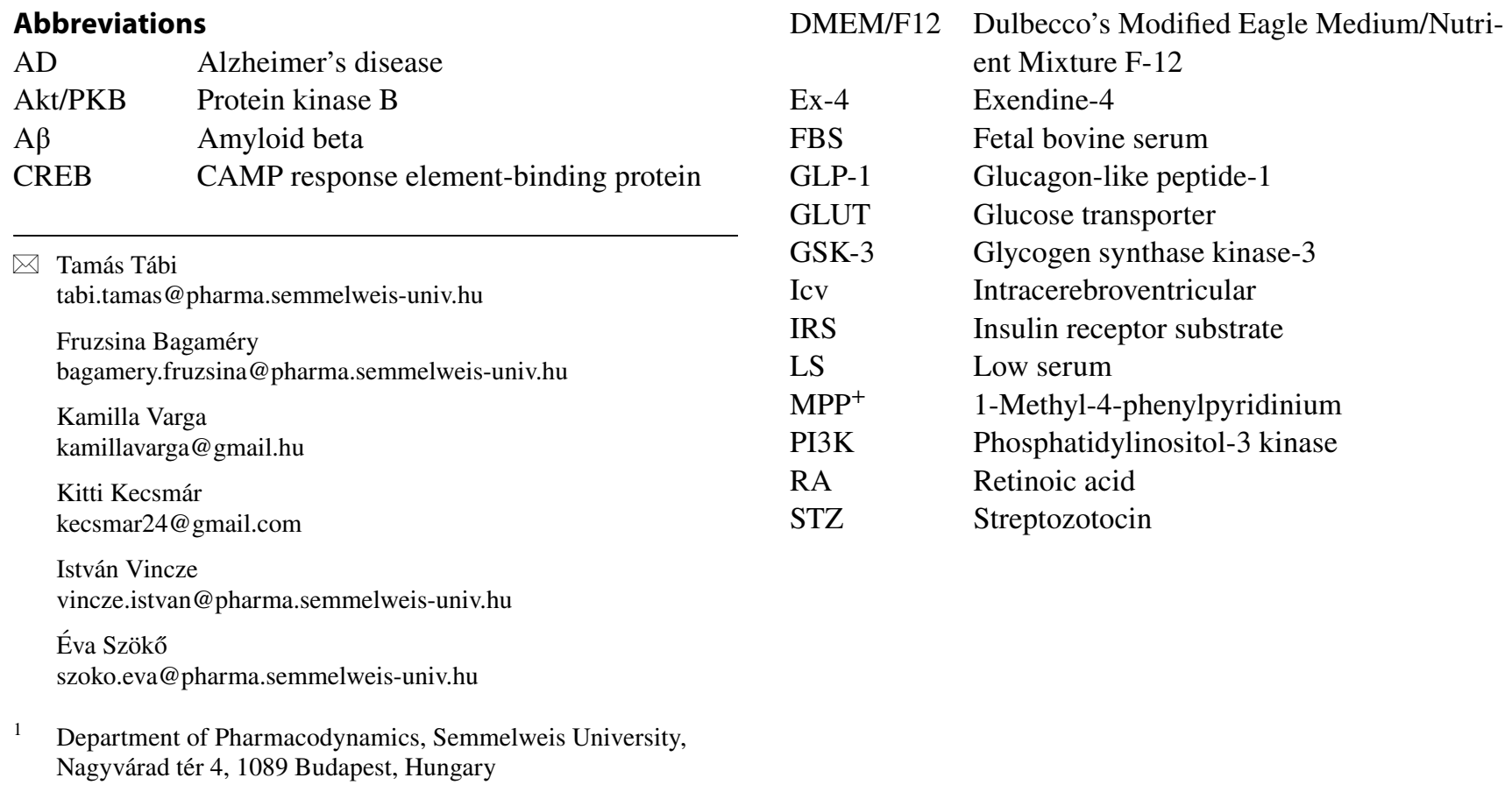




\section{Introduction}

One consequence of the progressive society aging is the rapid rising in the prevalence of Alzheimer's disease (AD) [1]. In the central nervous system insulin is not only responsible for metabolic regulation but neuroprotection and improving of cognitive processing are also among its major roles [2, 3]. It signals via the phosphatidylinositol-3 kinase (PI3K)-protein kinase B (Akt/PKB) pathway [4] that in turn phosphorylates and inactivates glycogen synthase kinase-3 (GSK-3) [5]. GSK-3 has two isoforms and both $\alpha$ and $\beta$ were shown associated with neurodegenerative processes, namely they participate in the development of tauopathy and amyloidopathy [6-8]. Insulin resistance has been recently suggested to contribute to the development of $\mathrm{AD}$ and cognitive decline $[2,3,9,10]$ that may be explained by the inappropriate regulation of GSK-3 [11-14].

Improvement of central insulin sensitivity might serve as a therapeutic tool to fight against neuronal degeneration in AD. Incretin hormones, like glucagon-like peptide-1 (GLP-1) are among the suggested neuroprotective agents acting by reducing insulin resistance in the brain (for review: [10]). Analogues of GLP-1, like exendin-4 (exenatide, Ex-4) were recently introduced to the therapy of type 2 diabetes. Besides its beneficial peripheral effects, Ex-4 was suggested mediating neuroprotection by potentiating central insulin signaling $[10,15]$. In in vitro studies on neural cell cultures its protective effects against various damaging conditions like oxidative stress [16, 17], hypoxia $[18]$ or $A \beta$ insult $[16,19]$ among others was revealed. Better understanding the role of insulin signaling in the central nervous system and its potential modulation by pharmacological tools like GLP-1 analogues therefore can facilitate the research of disease modifying therapy for AD.

Streptozotocin (STZ) treatment is one of the most established method for induction of impairment in the insulin system [20]. In in vivo experiments it can induce either type 1 or type 2 diabetes [21-23]. In addition, the compound was used as a diabetic neuropathic pain model because its administration results in the development of allodynia besides hyperglycemia [24, 25]. Furthermore, its local, intracerebroventricular (icv.) administration is also used to induce AD like brain damages characterized by elevated oxidative stress [26] and increased activity of GSK-3 $\beta[27,28]$ among others.

STZ is also used in in vitro experiments to explore the cellular mechanisms that might contribute to cell death in AD. It was found to have concentration-dependent cytotoxic effect in various neural cell types [29-32]. Mitochondrial damage [29, 32, 33], elevated reactive oxygen species production [34] and higher rate of apoptosis [33-35] were observed. Its effect on insulin system was also examined showing reduced expression of insulin receptor substrate (IRS)-1 [36], altered GSK-3 phosphorylation [31, 34] and increased tau protein phosphorylation [35]. Additionally, insulin was found to improve STZ induced cytotoxicity [29, 34].

In our previous experiments we studied the effect of STZ on insulin sensitivity of undifferentiated SH-SY5Y neuroblastoma cells. It induced concentration- and timedependent cytotoxicity that was concentration-dependently ameliorated by insulin with a potency similar to that seen in case of control damage induced by low serum medium (LS). Moreover, there was no significant difference in the insulin induced phosphorylation of GSK-3 between STZ and LS treatments indicating maintained insulin sensitivity in STZ treated undifferentiated SH-SY5Y cells [37]. Therefore, we concluded that STZ induces rather non-specific cytotoxicity to the undifferentiated cells without the development of significant insulin resistance, which might be explained by the high sensitivity of rapidly proliferating neuroblastoma cells to cytotoxic compounds like STZ [38].

SH-SY5Y cells can be differentiated to gain a more mature neuron-like phenotype. Although numerous differentiation methods exist, retinoic acid (RA) induced process is the most commonly used [39]. During differentiation among other altered cellular properties, decreased susceptibility to neurotoxins $[40,41]$ were observed. These findings indicate that differentiated neuroblastoma cells may serve as a more accurate translational model of human disease, therefore in our present study we aimed at examining the effect of STZ on cell viability and insulin signaling in RA differentiated SH-SY5Y cells.

\section{Materials and Methods}

\section{Materials}

Dulbecco's Modified Eagle Medium/Nutrient Mixture F-12 (DMEM/F12) and fetal bovine serum (FBS) were obtained from Corning (Tewksbury, MA, USA) and Biosera (Nuaille, France), respectively. Stable glutamine and Minimum Essential Medium non-essential amino acids solutions were purchased from Pan Biotech (Aidenbach, Germany). Insulin, Ex-4, resazurin based cell viability kit (TOX-8), Triton X-100, Phosphatase inhibitor cocktail 2 were obtained from Sigma (St. Louis, MO, USA). STZ was purchased from Cayman Chemical Company (Ann Arbor, MI, USA) and was dissolved in citrate buffer (0.1 M, pH 4.5) immediately before adding to the medium. DuoSet IC, Phospho-GSK$3 \alpha / \beta$ (S21/S9) ELISA kit was provided by R\&D Systems GmbH (Wiesbaden, Germany). 


\section{Cell Culture, Differentiation and Treatment}

Human neuroblastoma SH-SY5Y cells (ECACC, UK) were seeded to $10 \mathrm{~cm}$ Petri dishes $\left(4 \times 10^{5}\right.$ cells/dish) or 24 -well plates $\left(2 \times 10^{4}\right.$ cell/well) and were cultured in DMEM/F12 containing $3.15 \mathrm{~g} / \mathrm{L}$ glucose, $10 \% \mathrm{FBS}, 1 \%$ stable glutamine and antibiotics. For induction of differentiation $50 \mu \mathrm{M}$ RA was added to the culture medium on day 0 for 5 days. Culture medium was refreshed on the third day of differentiation.

Resazurin reduction cell viability assays were carried out in 24-well plates. After the 5-day-long differentiation the medium was changed to LS one that contained $1 \%$ FBS and treated by various concentrations of STZ $(0.3,1,3,5$, $7,10 \mathrm{mM}$ ). In some experiments the cells were simultaneously treated by insulin $(10,30,100,300,1000,3000 \mathrm{nM})$. The medium was refreshed daily, and insulin treatment was repeated alongside for up to 3 days. To determine the alteration of cell viability after STZ treatment the results were compared to the control damage, LS group. Furthermore, to assess the protective effect of insulin the rate of resazurin reducing activity in insulin treated or damage-only (STZ or LS alone) groups were analyzed.

For determination of GSK-3 phosphorylation the cells were treated by LS medium and $5 \mathrm{mM} \mathrm{STZ}$ after the 5-day differentiation. Twenty-four hours later the cells were treated with insulin $(10,30,100,300,1000,3000 \mathrm{nM})$ for $30 \mathrm{~min}$ then harvested in ice cold lysis buffer (1 mM EDTA, 0.5\% Triton X-100, $6 \mathrm{M}$ urea in PBS) containing Phosphatase inhibitor cocktail 2 and assayed by ELISA.

In some experiments, after the 5-day differentiation the cells were pretreated with $100 \mathrm{nM} \mathrm{Ex}-4$ in LS medium for $1 \mathrm{~h}$

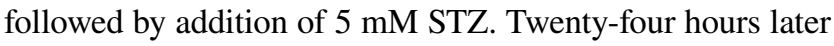
the cells were treated with insulin $(100 \mathrm{nM})$ in the presence or absence of Ex-4 (100 nM) for 30 min then harvested in Phosphatase inhibitor cocktail 2 containing ice cold lysis buffer.

The concentration of $5 \mathrm{mM} \mathrm{STZ}$ and $100 \mathrm{nM}$ insulin were chosen according to the results of our cell viability assays as these induced a low but significant cellular damage and a significant cytoprotection, respectively. The concentration of Ex-4 was chosen on the basis of the literature.

\section{Resazurin Reduction Cell Viability Assay}

Resazurin reduction was assessed according to the manufacturer's instructions. Briefly, after 24, 48 and $72 \mathrm{~h} \mathrm{STZ} \mathrm{treat-}$ ment the medium was replaced by fresh medium containing resazurin $(0.015 \mathrm{mg} / \mathrm{ml}$ final concentration $)$ and incubated for $4 \mathrm{~h}$ at $37^{\circ} \mathrm{C}$. The fluorescence of resorufin formed was measured by Fluoroskan Ascent FL microplate fluorimeter (Thermo Fisher Scientific, Waltham, MA USA) at 530 and $590 \mathrm{~nm}$ excitation and emission wavelengths, respectively. To characterize the cytoprotective effect of insulin, difference of resorufin fluorescence (RFU) between untreated and damaged cells was determined. Protection of each treatment was expressed as percent improvement in fluorescence:

$$
\begin{aligned}
\text { Protection }(\%)= & 100 \times\left(\mathrm{RFU}_{\text {treated }}-\mathrm{RFU}_{\text {damaged }}\right) / \\
& \left(\mathrm{RFU}_{\text {undamaged }}-\mathrm{RFU}_{\text {damaged }}\right)
\end{aligned}
$$

\section{ELISA Measurement}

GSK-3 phosphorylation was measured according to the manufacturer's instructions with some modifications. Briefly 100 $\mu \mathrm{L}$ cell lysate was added to the ELISA plate and incubated overnight at $4{ }^{\circ} \mathrm{C}$. After washing the plate was probed by detection antibody for $4 \mathrm{~h}$ at room temperature. The results were corrected by the protein content of the lysates measured by Bradford's method [42].

\section{Statistics}

Data are expressed as mean \pm standard error of the mean of at least 3 parallel measurements. One-way ANOVA was used for data analysis followed by Dunnett's post-hoc test for multiple comparisons. Concentration-response curves were constructed by non-linear regression method and the resulting estimates of Emax and EC50 were compared by F test. Corrected $\mathrm{p}<0.05$ was considered statistically significant. Data were analyzed by Prism 8 software (GraphPad Software Inc., La Jolla, CA, USA).

\section{Results}

\section{STZ Induced Cytotoxicity on Differentiated SH-SY5Y Cells}

The effect of STZ on cell viability was compared to that of LS condition on RA-differentiated SH-SY5Y cells exposed to $0.3,1,3,5,7,10 \mathrm{mM} \mathrm{STZ}$ in LS medium. Resazurin reduction assay was carried out after 24,48 and $72 \mathrm{~h}$.

Compared to the cytotoxic effect of LS treatment STZ further decreased the number of the metabolically active cells in a concentration-dependent manner. Lower concentrations, $0.3,1 \mathrm{mM}$ of STZ caused non-significant or mild decrease in cell viability, respectively, while higher concentrations $(7,10 \mathrm{mM})$ induced considerable decline in the number of viable cells. A significant but still moderate cytotoxicity could be observed after 3 or $5 \mathrm{mM} \mathrm{STZ} \mathrm{treatment}$ indicating the eligibility of both concentrations to model the chronic neurodegenerative processes. For the further experiments $5 \mathrm{mM}$ STZ treatment was chosen, compared to the LS condition it decreased the cell viability to $79.1 \%, 75.3 \%$ and $73.5 \%$ after 24, 48 and $72 \mathrm{~h}$, respectively (Fig. 1). 

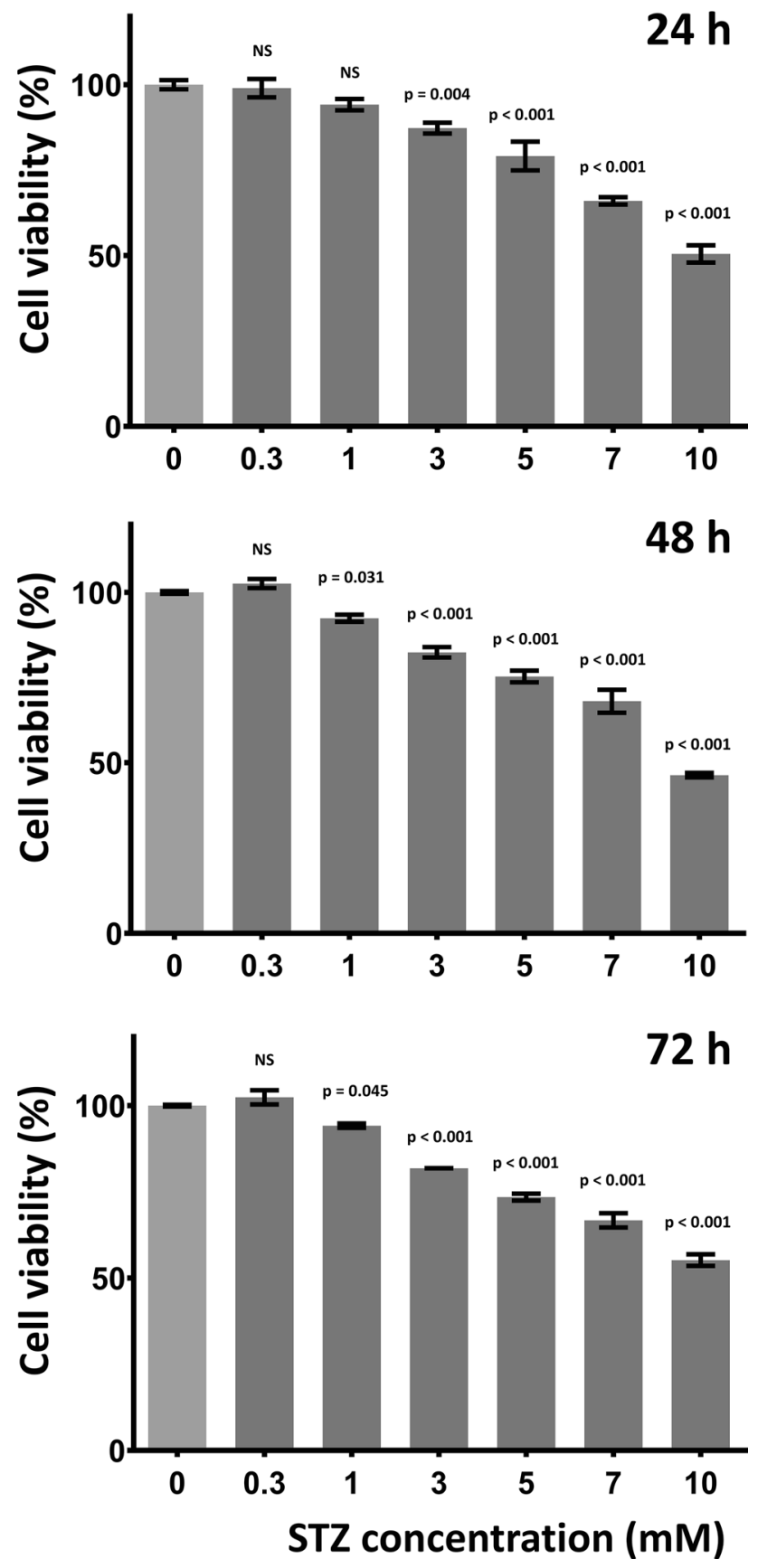

Fig. 1 STZ concentration-dependently decreased cell viability compared to the cells treated with LS medium alone. P values from oneway ANOVA and Dunnett's post hoc test compared to respective LS condition (0 mM STZ) are indicated, $N S$ non-significant

\section{Insulin was Cytoprotective in LS and STZ Treated Cells}

The impact of insulin was studied on both LS and $5 \mathrm{mM}$ STZ induced cytotoxicity. Cells were treated by various concentrations of insulin $(0,10,30,100,300,1000$,
$3000 \mathrm{nM}$ ) and their viability was estimated after 24,48 and $72 \mathrm{~h}$ by using resazurin assay.

In both LS and STZ treated cells insulin exerted concentration-dependent protective effect. In case of LS treatment insulin increased cell viability by $25-40 \%$, which was significantly higher than seen in case of STZ treated cells where the maximal achieved protection was between 10-25\% compared to the respective damage alone. The potency of insulin, however, was similar in both groups (Fig. 2).

\section{Insulin Induced GSK-3 Phosphorylation was Altered in STZ Treated Cells}

Insulin concentration-dependently elevated the level of phosphorylated GSK-3 in both LS and STZ treated cells. While the efficacy of insulin was similar, its potency was significantly different in the two groups. In the STZ treated cells the effective concentration of insulin was significantly higher as its dose response curve shifted to the right (Fig. 3). These data indicate the development of insulin resistance in the STZ treated cells compared to the LS group.

\section{Ex-4 Pretreatment Augmented the Insulin-Induced GSK-3 Phosphorylation in STZ Treated Cells}

Pretreatment with $100 \mathrm{nM} \mathrm{Ex}-4$ for $24 \mathrm{~h}$ had also a different impact on the insulin-induced GSK-3 phosphorylation in LS and STZ treated cells. In the LS group Ex-4 pretreatment did not alter significantly the $100 \mathrm{nM}$ insulin induced phosphorylation of GSK-3. However, in the STZ treated cells it significantly potentiated the effect of $100 \mathrm{nM}$ insulin on GSK-3 phosphorylation (Fig. 4) confirming the impaired insulin sensitivity in response to STZ treatment.

\section{Discussion}

Recently it has been suggested that impairment in brain insulin sensitivity can be an important factor in the complex pathomechanism of AD [28]. Some medications, such as intranasal insulin or GLP-1 analogues, like Ex-4 were shown to ameliorate the symptoms of the disease indicating that insulin signaling can be a potential medicinal target for treatment of AD [10, 15, 43, 44]. Numerous preclinical studies aim at investigating the precise mechanism of the disorder including the role of insulin signaling to facilitate the development of potential neuroprotective therapies.

In our previous in vitro study, we examined how insulin sensitivity of the undifferentiated SH-SY5Y neuroblastoma cells is influenced by STZ treatment. It was found to be suitable to induce a mild, gradual damage resembling to processes in chronic neurodegenerative disorders, however 

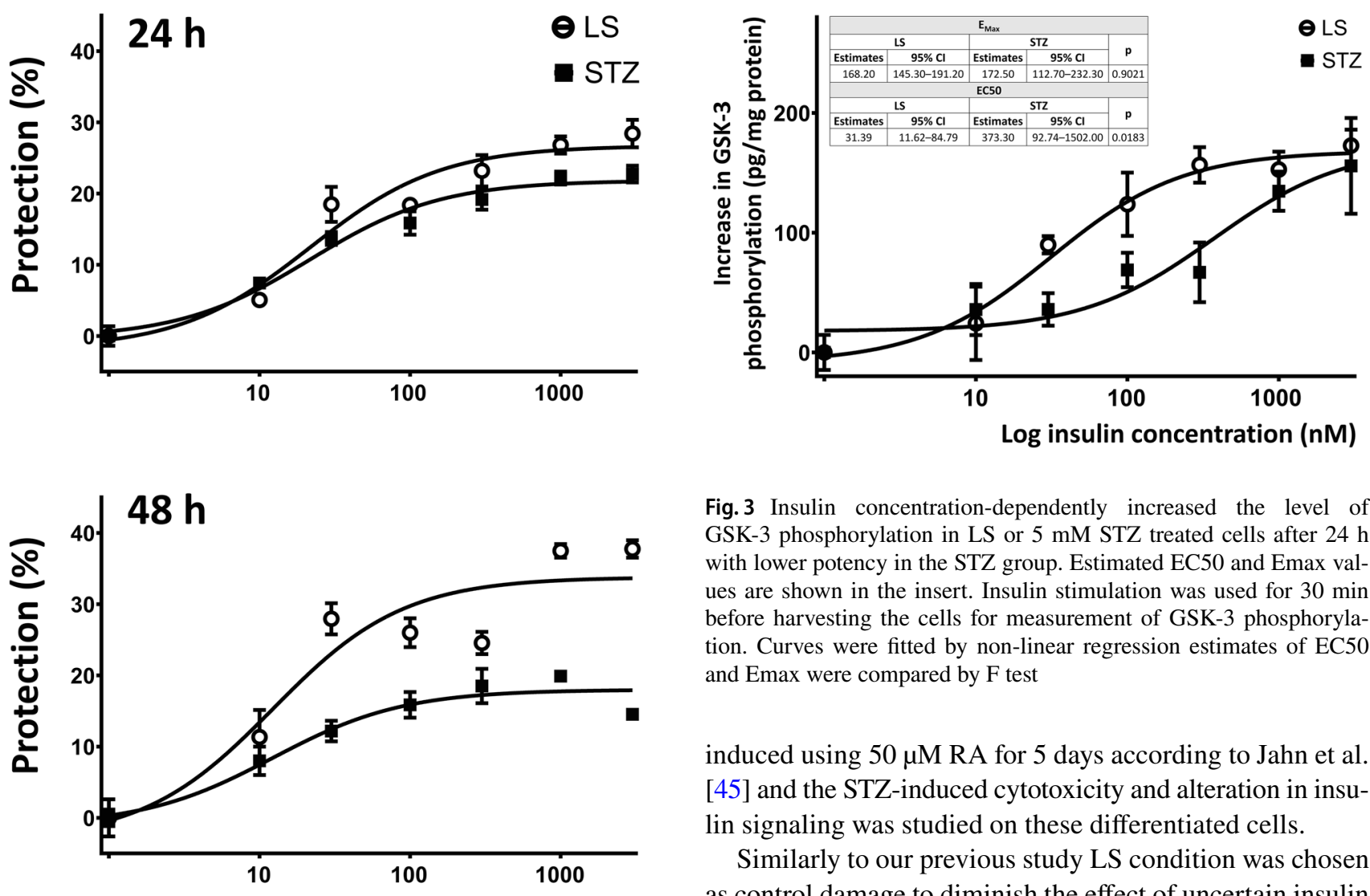

Fig. 3 Insulin concentration-dependently increased the level of GSK-3 phosphorylation in LS or $5 \mathrm{mM} \mathrm{STZ}$ treated cells after $24 \mathrm{~h}$ with lower potency in the STZ group. Estimated EC50 and Emax values are shown in the insert. Insulin stimulation was used for $30 \mathrm{~min}$ before harvesting the cells for measurement of GSK-3 phosphorylation. Curves were fitted by non-linear regression estimates of EC50 and Emax were compared by $F$ test

induced using $50 \mu \mathrm{M}$ RA for 5 days according to Jahn et al. [45] and the STZ-induced cytotoxicity and alteration in insulin signaling was studied on these differentiated cells.

Similarly to our previous study LS condition was chosen as control damage to diminish the effect of uncertain insulin concentration of FBS and as it is unlikely that insulin resistance develops due to reduced serum content of the medium

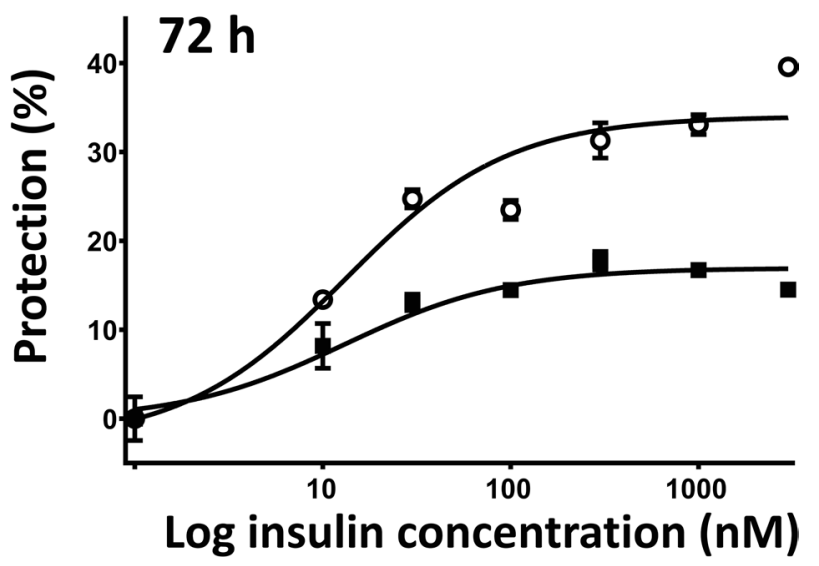
$[26,46]$. Previously in undifferentiated cells we found that $1 \mathrm{mM} \mathrm{STZ}$ caused a gradual time-dependent cellular damage [37], however this low concentration of the compound barely decreased the cell viability compared to the LS medium in the RA differentiated cells. To induce a low grade but reliable damage of these cells $3-5 \mathrm{mM} \mathrm{STZ}$ was needed. These findings are in accordance with the results of previous studies using similar undifferentiated cells like SK-N-MC human neuroblastoma cells or N2A mouse neuronal cell line [31, 33]. However, Isaev et al. reported that in immature cerebellar granule cells 3-4 mM STZ induced significant decrease in cell viability, while the mature cultures were hardly sensitive to this concentration [30] suggesting that not only cell type but its maturity is also a key factor in the sensitivity to neurotoxins. In addition, numerous papers reported that RA-induced differentiation of SHSY5Y cells decreased their susceptibility to various noxious stimuli. Tieu et al. found that RA-differentiated cells were less vulnerable against various cytotoxic insults such as cisplatin, 5-flurouracil, 6-hydroxydopamine and $\gamma$-radiation. They explained their results by decreased expression of p53 tumor suppressor gene and the increased antiapoptotic Bcl-2 gene expression [41]. Similar results were reported by Cheung et al. as they found that RA-differentiated SHSY5Y cell were less sensitive to 6-hydroxydopamine and 


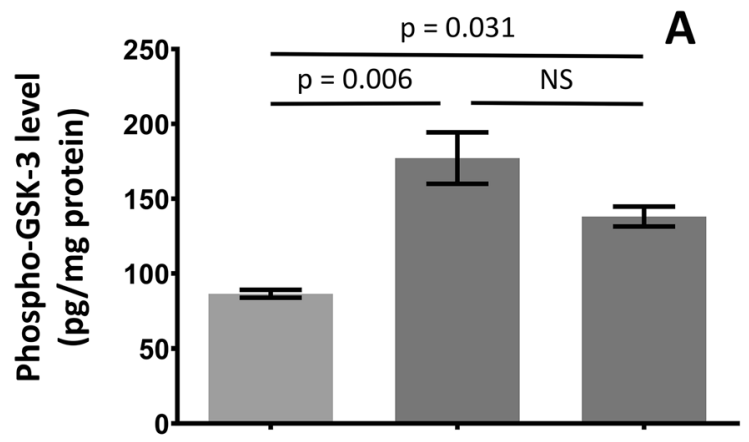

$\begin{array}{rc}\text { Damage } & \text { LS } \\ \text { Insulin } & - \\ \text { Ex-4 } & -\end{array}$

Fig. 4 Ex-4 enhanced insulin induced GSK-3 phosphorylation only in STZ treated cells. Cells were pretreated with $100 \mathrm{nM}$ of Ex-4 for $1 \mathrm{~h}$ before LS (a) or $5 \mathrm{mM} \mathrm{STZ} \mathrm{(b)} \mathrm{treatment.} \mathrm{After} 24 \mathrm{~h} 100 \mathrm{nM}$ insulin induced GSK-3 phosphorylation was measured by ELISA in

1-methyl-4-phenylpyridinium $\left(\mathrm{MPP}^{+}\right)$induced neurotoxicity [40]. In their experiments enhanced activity of neural survival signaling, i.e. increased PI3K/Akt activity was observed which was also reported by other groups [39, 47-49].

In previous studies cell damage induced by STZ was also found associated with impaired glucose metabolism and insulin signaling, such as reduction in the expression of glucose transporters in N2A neuronal and C6 glial cell lines [33], and that of insulin receptors [34] along with decreased phosphorylation of IRS-1 in SH-SY5Y cells [36] and dysregulation of GSK-3 activity in SK-N-MC cells [31]. In our previous study on undifferentiated SH-SY5Y cells STZinduced cellular damage was concentration-dependently attenuated by the concurrent insulin treatment that is accompanied by improved GSK-3 phosphorylation. However, no difference in the potency of insulin was seen compared to the control LS induced damage [37].

In our present study the effect of insulin in LS and STZ treated RA-differentiated SH-SY5Y cells was compared. Insulin concentration- and time-dependently improved the cell viability. However, it was considerably less effective compared to the undifferentiated cells as the maximum protective effect was only $10-25 \%$ and $25-40 \%$ in the STZ and LS treated groups, respectively. Our present results thus indicate a significant alteration in insulin sensitivity during differentiation. Even though considerably different maximum protective effect of insulin was found in the LS and STZ treated differentiated cells the EC50 values of insulin for improving cell viability did not differ significantly, suggesting that STZ treatment did not alter the ability of insulin
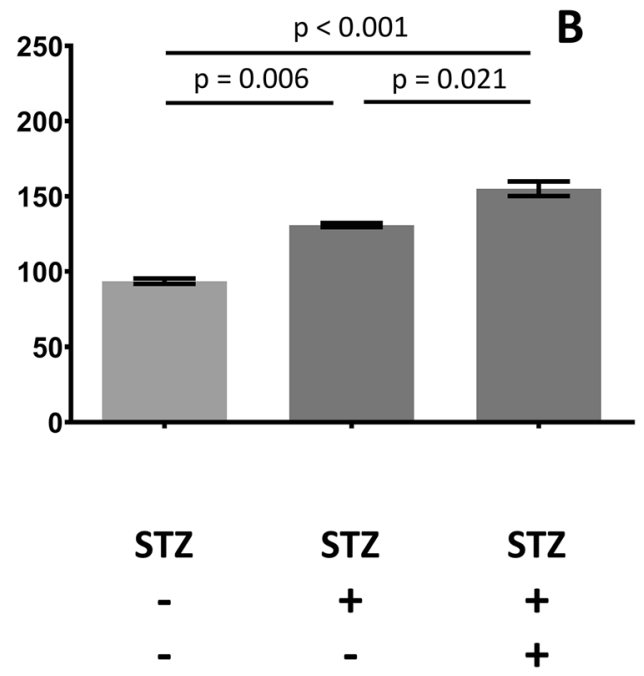

the presence or absence of simultaneous $100 \mathrm{nM} \mathrm{Ex}-4$ treatment. $\mathrm{P}$ values from one-way ANOVA and Dunnett's post hoc test compared to respective damage conditions are indicated, NS: non-significant

to promote neuronal survival even in RA-differentiated neuroblastoma cells. In both cases the efficacy of insulin was higher in LS groups, which could be explained by the more extensive damage induced by STZ.

GSK-3 was chosen to assess the activity of insulin signaling, as it is known to have an important role in neurodegenerative processes. The enzyme is regulated by various pathways, not exclusively by insulin, although its insulin induced phosphorylation can be suitable to examine the potential development of insulin resistance. We found that insulin concentration-dependently elevated GSK-3 phosphorylation in both LS and STZ treated cells, but its dose-response curve significantly shifted to the right in the STZ treated group indicating reduced insulin sensitivity of the STZ treated cells. This is in accordance with the findings of in vivo studies that showed STZ treatment induced insulin resistance both in the periphery [20] and the central nervous system [27, 28]. Since in our previous works on undifferentiated SH-SY5Y cells development of insulin resistance could not be observed [37], we can assume that the differentiation may induce alterations in the insulin signaling of the cells, that can make them more sensitive to the specific effect of STZ while its non-specific cytotoxic action was lower.

To further verify the impairment of insulin signaling in the STZ treated cells the effect of an incretin analogue, Ex-4 was also studied. Ex-4 was reported to improve neuronal insulin resistance both in vivo [50] and in vitro [15] experiments by preventing pathological phosphorylation of IRS-1, which interferes with its function to activate the downstream signaling cascade of insulin. The protective effect of Ex-4 is likely mediated by activation of GLP-1 
receptors [15]. Ex-4 is frequently used in cell cultures as a potential neuroprotective agent. The compound prevented the damage induced by hydrogen peroxide $[16,17], A \beta$ $[16,19]$, staurosporin [17], glutamate [51, 52] in various neural cultures in $10^{-7} \mathrm{M}$ concentration range.

In our present experiments pretreatment of cells with $100 \mathrm{nM} \mathrm{Ex}-4$, a concentration that proved to be effective in various neuronal models $[16-19,51]$ significantly improved the insulin induced GSK-3 phosphorylation in STZ treated cells, while a similar improvement could not be observed in the LS group. This also indicates and confirms the presence of insulin resistance in the STZ treated differentiated SH-SY5Y cells.

To the best of our knowledge, we are first to present a suitable model to induce neuronal insulin resistant state in the frequently used SH-SY5Y neuronal cell line using STZ. However; limitations of our proposed model involve that apart from the development of insulin resistance in the differentiated cells the presence of considerable nonspecific cytotoxicity of the compound must be taken into consideration too. Also, SH-SY5Y cells are not directly differentiated toward cholinergic phenotype and the role of other cell types of central nervous system too, such as microglias, oligodendrocytes and astroglias are not involved in our study. Therefore a possible improvement of our model may be altering the differentiation method e.g. directing it towards a more specific cholinergic phenotype [53] or using three-dimensional culture of SH-SY5Y cells to gain neurons with similar morphology and biochemistry like human neurons [54].

\section{Conclusion}

Based on our previous [37] and present findings we can conclude that STZ treatment has distinct effect on the undifferentiated and RA-differentiated SH-SY5Y cells. Differentiation reduces the susceptibility of the cells for the direct cytotoxic effect of STZ and induces alterations that makes them more prone to its effect inducing insulin resistance. The STZ-treated differentiated SH-SY5Y cells thus are promising tools for studying the alterations in neuronal insulin signaling.

Acknowledgements The authors acknowledge the financial support of Association for Regional Cooperation in the Fields of Health, the Science and Technology (RECOOP HST) and the National Scientific Research Fund of Hungary (2018-1.3.1-VKE-2018-00030). The valuable technical assistance of Ms. Valéria Szanics is highly appreciated.

Funding Open access funding provided by Semmelweis University.
Data Availability The datasets generated during and/or analysed during the current study are available from the corresponding author on reasonable request.

\section{Compliance with Ethical Standards}

Conflict of interest The author declare that they have no conflict of interest.

Open Access This article is licensed under a Creative Commons Attribution 4.0 International License, which permits use, sharing, adaptation, distribution and reproduction in any medium or format, as long as you give appropriate credit to the original author(s) and the source, provide a link to the Creative Commons licence, and indicate if changes were made. The images or other third party material in this article are included in the article's Creative Commons licence, unless indicated otherwise in a credit line to the material. If material is not included in the article's Creative Commons licence and your intended use is not permitted by statutory regulation or exceeds the permitted use, you will need to obtain permission directly from the copyright holder. To view a copy of this licence, visit http://creativecommons.org/licenses/by/4.0/.

\section{References}

1. Crous-Bou M, Minguillon C, Gramunt N, Molinuevo JL (2017) Alzheimer's disease prevention: from risk factors to early intervention. Alzheimers Res Ther 9(1):71. https://doi.org/10.1186/ s13195-017-0297-z

2. Kullmann S, Heni M, Hallschmid M, Fritsche A, Preissl H, Haring HU (2016) Brain Insulin Resistance at the Crossroads of Metabolic and Cognitive Disorders in Humans. Physiol Rev 96(4):1169-1209. https://doi.org/10.1152/physrev.00032.2015

3. Santiago JCP, Hallschmid M (2019) Outcomes and clinical implications of intranasal insulin administration to the central nervous system. Exp Neurol 317:180-190. https://doi.org/10.1016/j.expne urol.2019.03.007

4. Johnston AM, Pirola L, Van Obberghen E (2003) Molecular mechanisms of insulin receptor substrate protein-mediated modulation of insulin signalling. FEBS Lett 546(1):32-36. https://doi. org/10.1016/s0014-5793(03)00438-1

5. Cross DA, Alessi DR, Cohen P, Andjelkovich M, Hemmings BA (1995) Inhibition of glycogen synthase kinase- 3 by insulin mediated by protein kinase B. Nature 378(6559):785-789. https://doi. org/10.1038/378785a0

6. Ishiguro K, Shiratsuchi A, Sato S, Omori A, Arioka M, Kobayashi S, Uchida T, Imahori K (1993) Glycogen synthase kinase 3 beta is identical to tau protein kinase I generating several epitopes of paired helical filaments. FEBS Lett 325(3):167-172. https://doi. org/10.1016/0014-5793(93)81066-9

7. Leroy K, Boutajangout A, Authelet M, Woodgett JR, Anderton $\mathrm{BH}$, Brion JP (2002) The active form of glycogen synthase kinase3beta is associated with granulovacuolar degeneration in neurons in Alzheimer's disease. Acta Neuropathol 103(2):91-99. https:// doi.org/10.1007/s004010100435

8. Solano DC, Sironi M, Bonfini C, Solerte SB, Govoni S, Racchi M (2000) Insulin regulates soluble amyloid precursor protein release via phosphatidyl inositol 3 kinase-dependent pathway. FASEB J 14(7):1015-1022. https://doi.org/10.1096/fasebj.14.7.1015

9. Talbot K (2013) Brain insulin resistance in alzheimer disease and its potential treatment with a mediterranean diet and GLP-1 analogues. Psychiatr Times. https://doi.org/10.2337/dc12-2074) 
10. Talbot K, Wang HY (2014) The nature, significance, and glucagon-like peptide-1 analog treatment of brain insulin resistance in Alzheimer's disease. Alzheimers Dement 10(1 Suppl):S12-25. https://doi.org/10.1016/j.jalz.2013.12.007

11. de la Monte SM (2012) Contributions of brain insulin resistance and deficiency in amyloid-related neurodegeneration in Alzheimer's disease. Drugs 72(1):49-66. https://doi.org/10.2165/11597 760-000000000-00000

12. Hoyer S, Muller D, Plaschke K (1994) Desensitization of brain insulin receptor. Effect on glucose/energy and related metabolism. J Neural Transm Suppl 44:259-268

13. Salkovic-Petrisic M, Hoyer S (2007) Central insulin resistance as a trigger for sporadic Alzheimer-like pathology: an experimental approach. J Neural Transm Suppl 72:217-233

14. Takeda S, Sato N, Rakugi H, Morishita R (2011) Molecular mechanisms linking diabetes mellitus and Alzheimer disease: beta-amyloid peptide, insulin signaling, and neuronal function. Mol BioSyst 7(6):1822-1827. https://doi.org/10.1039/c0mb0 $0302 \mathrm{f}$

15. Bomfim TR, Forny-Germano L, Sathler LB, Brito-Moreira J, Houzel JC, Decker H, Silverman MA, Kazi H, Melo HM, McClean PL, Holscher C, Arnold SE, Talbot K, Klein WL, Munoz DP, Ferreira ST, De Felice FG (2012) An anti-diabetes agent protects the mouse brain from defective insulin signaling caused by Alzheimer's disease- associated Abeta oligomers. J Clin Investig 122(4):1339-1353. https://doi.org/10.1172/jci57256

16. Li Y, Duffy KB, Ottinger MA, Ray B, Bailey JA, Holloway HW, Tweedie D, Perry T, Mattson MP, Kapogiannis D, Sambamurti K, Lahiri DK, Greig NH (2010) GLP-1 receptor stimulation reduces amyloid-beta peptide accumulation and cytotoxicity in cellular and animal models of Alzheimer's disease. J Alzheimers Dis 19(4):1205-1219. https://doi.org/10.3233/jad-2010-1314

17. Li Y, Chigurupati S, Holloway HW, Mughal M, Tweedie D, Bruestle DA, Mattson MP, Wang Y, Harvey BK, Ray B, Lahiri DK, Greig NH (2012) Exendin-4 ameliorates motor neuron degeneration in cellular and animal models of amyotrophic lateral sclerosis. PLoS ONE 7(2):e32008. https://doi.org/10.1371/journ al.pone.0032008

18. Li Y, Perry T, Kindy MS, Harvey BK, Tweedie D, Holloway HW, Powers K, Shen H, Egan JM, Sambamurti K, Brossi A, Lahiri DK, Mattson MP, Hoffer BJ, Wang Y, Greig NH (2009) GLP-1 receptor stimulation preserves primary cortical and dopaminergic neurons in cellular and rodent models of stroke and Parkinsonism. Proc Natl Acad Sci USA 106(4):1285-1290. https://doi. org/10.1073/pnas.0806720106

19. Qiu C, Wang YP, Pan XD, Liu XY, Chen Z, Liu LB (2016) Exendin-4 protects Abeta(1-42) oligomer-induced PC12 cell apoptosis. Am J Transl Res 8(8):3540-3548

20. Radenkovic M, Stojanovic M, Prostran M (2016) Experimental diabetes induced by alloxan and streptozotocin: The current state of the art. J Pharmacol Toxicol Methods 78:13-31. https://doi. org/10.1016/j.vascn.2015.11.004

21. Like AA, Rossini AA (1976) Streptozotocin-induced pancreatic insulitis: new model of diabetes mellitus. Science (New York, NY) 193(4251):415-417. https://doi.org/10.1126/science.180605

22. Reaven GM, Ho H (1991) Low-dose streptozotocin-induced diabetes in the spontaneously hypertensive rat. Metabolism 40(4):335337. https://doi.org/10.1016/0026-0495(91)90141-i

23. Wang Z, Gleichmann H (1998) GLUT2 in pancreatic islets: crucial target molecule in diabetes induced with multiple low doses of streptozotocin in mice. Diabetes 47(1):50-56. https://doi. org/10.2337/diab.47.1.50

24. Balogh M, Zádor F, Zádori ZS, Shaqura M, Király K, Mohammadzadeh A, Varga B, Lázár B, Mousa SA, Hosztafi S, Riba P, Benyhe S, Gyires K, Schäfer M, Fürst S, Al-Khrasani M (2019) Efficacy-Based Perspective to Overcome Reduced Opioid
Analgesia of Advanced Painful Diabetic Neuropathy in Rats. Front Pharmacol 10:347. https://doi.org/10.3389/fphar.2019.00347

25. Chen SR, Zhang J, Chen H, Pan HL (2019) StreptozotocinInduced Diabetic Neuropathic Pain Is Associated with Potentiated Calcium-Permeable AMPA Receptor Activity in the Spinal Cord. J Pharmacol Exp Ther 371(2):242-249. https://doi.org/10.1124/ jpet.119.261339

26. Deshmukh M, Johnson EM Jr (1997) Programmed cell death in neurons: focus on the pathway of nerve growth factor deprivationinduced death of sympathetic neurons. Mol Pharmacol 51(6):897906. https://doi.org/10.1124/mol.51.6.897

27. Deng Y, Li B, Liu Y, Iqbal K, Grundke-Iqbal I, Gong CX (2009) Dysregulation of insulin signaling, glucose transporters, O-GlcNAcylation, and phosphorylation of tau and neurofilaments in the brain: Implication for Alzheimer's disease. Am J Pathol 175(5):2089-2098. https://doi.org/10.2353/ajpath.2009.090157

28. Salkovic-Petrisic M, Tribl F, Schmidt M, Hoyer S, Riederer P (2006) Alzheimer-like changes in protein kinase B and glycogen synthase kinase- 3 in rat frontal cortex and hippocampus after damage to the insulin signalling pathway. J Neurochem 96(4):1005-1015. https://doi.org/10.111 $1 / \mathrm{j} .1471-4159.2005 .03637 . x$

29. Genrikhs EE, Stelmashook EV, Golyshev SA, Aleksandrova OP, Isaev NK (2017) Streptozotocin causes neurotoxic effect in cultured cerebellar granule neurons. Brain Res Bull 130:90-94. https://doi.org/10.1016/j.brainresbull.2017.01.004

30. Isaev NK, Genrikhs EE, Voronkov DN, Kapkaeva MR, Stelmashook EV (2018) Streptozotocin toxicity in vitro depends on maturity of neurons. Toxicol Appl Pharmacol 348:99-104. https://doi.org/10.1016/j.taap.2018.04.024

31. Plaschke K, Kopitz J (2015) In vitro streptozotocin model for modeling Alzheimer-like changes: effect on amyloid precursor protein secretases and glycogen synthase kinase-3. J Neural Transm (Vienna, Austria: 1996) 122(4):551-557. https://doi. org/10.1007/s00702-014-1319-7

32. Park J, Won J, Seo J, Yeo HG, Kim K, Kim YG, Jeon CY, Kam MK, Kim YH, Huh JW, Lee SR, Lee DS, Lee Y (2020) Streptozotocin Induces Alzheimer's Disease-Like Pathology in Hippocampal Neuronal Cells via CDK5/Drp1-Mediated Mitochondrial Fragmentation. Front Cell Neurosci 14:235. https:// doi.org/10.3389/fncel.2020.00235

33. Biswas J, Gupta S, Verma DK, Singh S (2017) Streptozotocin alters glucose transport, connexin expression and endoplasmic reticulum functions in neurons and astrocytes. Neuroscience 356:151-166. https://doi.org/10.1016/j.neuroscien ce.2017.05.018

34. Rajasekar N, Dwivedi S, Nath C, Hanif K, Shukla R (2014) Protection of streptozotocin induced insulin receptor dysfunction, neuroinflammation and amyloidogenesis in astrocytes by insulin. Neuropharmacology 86:337-352. https://doi.org/10.1016/j.neuro pharm.2014.08.013

35. Biswas J, Goswami P, Gupta S, Joshi N, Nath C, Singh S (2016) Streptozotocin Induced Neurotoxicity Involves Alzheimer's Related Pathological Markers: a Study on N2A Cells. Mol Neurobiol 53(5):2794-2806. https://doi.org/10.1007/s12035-015-9144-Z

36. Wang P, Jiang S, Cui Y, Yue Z, Su C, Sun J, Sheng S, Tian J (2011) The n-terminal 5-MER peptide analogue P165 of amyloid precursor protein exerts protective effects on SH-SY5Y cells and rat hippocampus neuronal synapses. Neuroscience 173:169-178. https://doi.org/10.1016/j.neuroscience.2010.10.069

37. Bagamery F, Varga K, Kecsmar K, Vincze I, Szoko E, Tabi T (2020) Lack of insulin resistance in response to streptozotocin treatment in neuronal SH-SY5Y cell line. J Neural Transm 127(1):71-80. https://doi.org/10.1007/s00702-019-02118-5 
38. Xie HR, Hu LS, Li GY (2010) SH-SY5Y human neuroblastoma cell line: in vitro cell model of dopaminergic neurons in Parkinson's disease. Chin Med J (Engl) 123(8):1086-1092

39. Kovalevich J, Langford D (2013) Considerations for the use of SH-SY5Y neuroblastoma cells in neurobiology. Methods Mol Biol 1078:9-21. https://doi.org/10.1007/978-1-62703-640-5_2

40. Cheung YT, Lau WK, Yu MS, Lai CS, Yeung SC, So KF, Chang RC (2009) Effects of all-trans-retinoic acid on human SH-SY5Y neuroblastoma as in vitro model in neurotoxicity research. Neurotoxicology 30(1):127-135. https://doi.org/10.1016/j.neuro 2008.11.001

41. Tieu K, Zuo DM, Yu PH (1999) Differential effects of staurosporine and retinoic acid on the vulnerability of the SH-SY5Y neuroblastoma cells: involvement of bcl-2 and p53 proteins. J Neurosci Res 58(3):426-435

42. Bradford MM (1976) A rapid and sensitive method for the quantitation of microgram quantities of protein utilizing the principle of protein-dye binding. Anal Biochem 72:248-254. https://doi. org/10.1006/abio.1976.9999

43. Chapman CD, Schioth HB, Grillo CA, Benedict C (2018) Intranasal insulin in Alzheimer's disease: Food for thought. Neuropharmacology 136(Pt B):196-201. https://doi.org/10.1016/j.neuro pharm.2017.11.037

44. Freiherr J, Hallschmid M, Frey WH 2nd, Brunner YF, Chapman CD, Holscher C, Craft S, De Felice FG, Benedict C (2013) Intranasal insulin as a treatment for Alzheimer's disease: a review of basic research and clinical evidence. CNS Drugs 27(7):505-514. https://doi.org/10.1007/s40263-013-0076-8

45. Jahn K, Wieltsch C, Blumer N, Mehlich M, Pathak H, Khan AQ, Hildebrandt H, Frieling H (2017) A cell culture model for investigation of synapse influenceability: epigenetics, expression and function of gene targets important for synapse formation and preservation in SH-SY5Y neuroblastoma cells differentiated by retinoic acid. J Neural Transm 124(11):1341-1367. https://doi. org/10.1007/s00702-017-1769-9

46. Li D, Zhu B, Ding L, Lu W, Xu G, Wu J (2014) Role of the mitochondrial pathway in serum deprivation-induced apoptosis of rat endplate cells. Biochem Biophys Res Commun 452(3):354-360. https://doi.org/10.1016/j.bbrc.2014.08.054

47. Eves EM, Xiong W, Bellacosa A, Kennedy SG, Tsichlis PN, Rosner MR, Hay N (1998) Akt, a target of phosphatidylinositol 3-kinase, inhibits apoptosis in a differentiating neuronal cell line. Mol Cell Biol 18(4):2143-2152. https://doi.org/10.1128/ mcb.18.4.2143

48. Lopez-Carballo G, Moreno L, Masia S, Perez P, Barettino D (2002) Activation of the phosphatidylinositol 3-kinase/Akt signaling pathway by retinoic acid is required for neural differentiation of SH-SY5Y human neuroblastoma cells. J Biol Chem 277(28):25297-25304. https://doi.org/10.1074/jbc.M201869200

49. Ramalingam M, Kim SJ (2015) Insulin exerts neuroprotective effects via Akt/Bcl-2 signaling pathways in differentiated $\mathrm{SH}-$ SY5Y cells. J Recept Signal Transduct Res 35(1):1-7. https:// doi.org/10.3109/10799893.2014.922576

50. Talbot K (2014) Brain insulin resistance in Alzheimer's disease and its potential treatment with GLP-1 analogs. Neurodegener Dis Manag 4(1):31-40. https://doi.org/10.2217/nmt.13.73

51. Li Y, Bader M, Tamargo I, Rubovitch V, Tweedie D, Pick CG, Greig NH (2015) Liraglutide is neurotrophic and neuroprotective in neuronal cultures and mitigates mild traumatic brain injury in mice. J Neurochem 135(6):1203-1217. https://doi.org/10.1111/ jnc. 13169

52. Perry T, Haughey NJ, Mattson MP, Egan JM, Greig NH (2002) Protection and reversal of excitotoxic neuronal damage by glucagon-like peptide-1 and exendin-4. J Pharmacol Exp Ther 302(3):881-888. https://doi.org/10.1124/jpet.102.037481

53. de Medeiros LM, De Bastiani MA, Rico EP, Schonhofen P, Pfaffenseller B, Wollenhaupt-Aguiar B, Grun L, Barbé-Tuana F, Zimmer ER, Castro MAA, Parsons RB, Klamt F (2019) Cholinergic Differentiation of Human Neuroblastoma SH-SY5Y Cell Line and Its Potential Use as an In vitro Model for Alzheimer's Disease Studies. Mol Neurobiol 56(11):7355-7367. https://doi. org/10.1007/s12035-019-1605-3

54. Agholme L, Lindström T, Kågedal K, Marcusson J, Hallbeck M (2010) An in vitro model for neuroscience: differentiation of SHSY5Y cells into cells with morphological and biochemical characteristics of mature neurons. J Alzheimers Dis 20(4):1069-1082. https://doi.org/10.3233/jad-2010-091363

Publisher's Note Springer Nature remains neutral with regard to jurisdictional claims in published maps and institutional affiliations. 